\title{
PENGEMBANGAN LEMBAR KERJA SISWA (LKS) BERBASIS CONTEXTUAL TEACHING AND LEARNING (CTL) PADA MATERI BARISAN DAN DERET SISWA KELAS XI SMA NEGERI 8 KOTA JAMBI
}

\author{
Pitria Arpani ${ }^{1}$, Buyung ${ }^{2}$, Relawati $^{3}$ \\ Program Studi Pendidikan Matematika, FKIP, Universitas Batanghari ${ }^{1,2,3}$ \\ Jl. Slamet Riyadi No.1 Broni Jambi \\ e-mail: -
}

\begin{abstract}
ABSTRAK
Penelitian ini merupakan penelitian Research and Development (R \& D) yang bertujuan menghasilkan produk LKS matematika yang berbasis pada Contextual Teaching and Learning dalam urutan dan seri materi yang dilihat dari kriteria, kepraktisan, validitas dan efektifitas. Penelitian ini mengacu pada model pengembangan ADDIE yang meliputi lima tahap: analisis, desain, pengembangan, implementasi dan evaluasi, dan subyek yang digunakan dalam penelitian ini adalah (a) lembar validasi untuk ahli materi, ahli desain dan ahli media yang berfungsi untuk menentukan validitas lembar kerja, (b) kuesioner respons siswa yang berfungsi untuk menentukan kepraktisan LKS dan (c) soal-soal posttest yang berfungsi untuk menentukan keefektifan LKS. Hasil penelitian menunjukkan bahwa LKS berdasarkan pembelajaran kontekstual di kelas dan materi urut siswa kelas XI dikategorikan baik dan cocok untuk digunakan sebagai alat belajar dilihat dari hasil validasi ahli yang diperoleh skor rata-rata 4,3 dengan persentase $86 \%$, diklasifikasikan dalam kategori praktis terlihat dari hasil angket tanggapan siswa yang mendapat skor ratarata 4,37 dengan persentase $80 \%$, dan tergolong efektif dilihat dari hasil perhitungan kelengkapan siswa dari soal-soal post-test yang diperoleh skor rata-rata 0,925 dengan persentase $92,5 \%$.
\end{abstract}

\section{Kata kunci:}

Pengembangan, Lembar Kerja Siswa (LKS), Pengajaran dan Pembelajaran Kontekstual (CTL), ADDIE

\begin{abstract}
This research is a Research and Development $(R \& D)$ research that aims to produce a product in the form of mathematics LKS based on Contextual Teaching and Learning in the sequence and series material seen from the criteria, practicality, validity and effectiveness. This study refers to the ADDIE development model which includes five stages: analysis, design, development, implementation and evaluation, and the subjects used in this study are (a) validation sheets for experts material, design experts and media experts who function to determine the validity of worksheets, (b) student response questionnaires which function to determine the practicality of LKS and (c) post-test questions that function to determine the effectiveness of LKS. The results showed that worksheets based on contextual teaching and learning in the class and sequence material of class XI students were categorized as good and suitable to be used as a learning tool seen from the results of expert validation which obtained an average score of 4.3 with a percentage of $86 \%$, classified in the category practically seen from the results of the questionnaire responses of students who received an average score of 4.37 with a percentage of $80 \%$, and classified as effective as seen from the calculation of students completeness of the post-test questions that obtained an average score of 0.925 with a percentage of $92.5 \%$.
\end{abstract}

Keyword:

Development, Student Worksheet (LKS), Contextual Teaching andLearning (CTL), ADDIE 


\section{PENDAHULUAN}

Matematika merupakan mata pelajaran yang dipelajari di setiap jenjang pendidikan dari tingkat SD sampai SMA bahkan perguruan tinggi. Salah satu tujuan pembelajaran matematika di sekolah adalah agar siswa memiliki sikap menghargai kegunaan matematika dalam kehidupan, yaitu memiliki rasa ingin tahu, perhatian, dan minat dalam mempelajari matematika, serta sikap ulet dan percaya diri dalam pemecahan masalah (Hastratudin, 2014). Salah satu upaya yang ditempuh untuk mencapai tujuan tersebut adalah melalui penyempurnaan kurikulum.Kurikulum terbaru yang telah diimplementasikan sekarang ini khususnya di SMA Negeri 8 Kota Jambi adalah Kurikulum 2013.

Berdasarkan Peraturan Menteri Pendidikan dan Kebudayaan (Permendikbud) No 69 Tahun 2013 tentang kerangka dasar dan struktur kurikulum SMA/MA, matematika di SMA masuk ke dalam kelompok mata pelajaran wajib dan mata pelajaran peminatan. Kelompok mata pelajaran wajib merupakan bagian dari pendidikan umum yaitu pendidikan bagi semua warga negara yang bertujuan memberikan pengetahuan tentang bangsa, sikap sebagai bangsa, dan kemampuan penting untuk mengembangkan kehidupan pribadi peserta didik, masyarakat, dan bangsa.Sementara itu kelompok mata pelajaran peminatan bertujuan untuk memberikan kesempatan kepada siswa untuk mengembangkan minatnya dalam sekelompok mata pelajaran yang sesuai dengan minat keilmuannya di perguruan tinggi dan untuk mengembangkan minatnya terhadap suatu disiplin ilmu atau keterampilan tertentu.

Berkaitan dengan bagaimana mengimplementasikan Kurikulum 2013, telah diatur dalam Peraturan mentri pendidikan dan kebudayaan (Permendikbud) Nomor 103 Tahun 2014 tentang Pembelajaran pada Pendidikan Dasar dan Pendidikan Menengah, yaitu untuk mencapai pembelajaran yang berkualitas, pembelajaran perlu menerapkan beberapa prinsip yaitu: (1) siswa difasilitasi untuk mencari tahu, (2) siswa belajar dari berbagai sumber belajar, (3) proses pembelajaran menggunakan pendekatan ilmiah, (4) pembelajaran berbasis kompetensi, (5) pembelajaran terpadu, (6) pembelajaran yang menekankan pada jawaban divergen yang memiliki kebenaran multi dimensi, (7) pembelajaran berbasis keterampilan aplikatif, (8) peningkatan

keseimbangan,kesinambungan, dan keterkaitan antara hard-skills dan softskills, (9) pembelajaran yang mengutamakan pembudayaan dan pemberdayaan siswa sebagai pembelajar sepanjang hayat, (10) pembelajaran yang menerapkan nilainilai dengan memberi keteladanan (ing ngarso sung tulodo), membangun kemauan (ingmadyo mangun karso), dan mengembangkan kreativitas siswa dalam proses pembelajaran (tut wuri handayani), (11) pembelajaran yang berlangsung di rumah, di sekolah, dan di masyarakat, (12) pemanfaatan teknologi informasi dan komunikasi untuk meningkatkan efisiensi dan efektivitas pembelajaran, (13) pengakuan atas perbedaan individual dan latar belakang budaya siswa, dan (14) suasana belajar menyenangkan dan menantang. Selain itu, dalam pembelajaran siswa didorong untuk menemukan sendiri dan mentranformasikan informasi kompleks, mengecek informasi baru dengan yang sudah ada dalam 


\section{$\pi$ (Phi)}

ingatannya, dan dikembangkan menjadi informasi atau kemampuan yang sesuai dengan lingkungan dan jaman tempat dan waktu ia hidup.

Berdasarkan uraian di atas maka dapat diketahui bahwa pembelajaran matematika di SMA berdasarkan Kurikulum 2013 tidak hanya bertujuan agar perlu adanya perangkat pembelajaran yang antara lain meliputi penyusunan rencana pelaksanaan pembelajaran dan penyiapan media dan sumber belajar, perangkat penilaian pembelajaran, dan skenario pembelajaran. Salah satu komponen yang harus ada di dalam salah satu perangkat pembelajaran sumber belajar. Sumber belajar ini dapat berupa buku, media cetak dan elektronik, Lembar Kegiatan Siswa (LKS), alam sekitar, atau sumber belajar lain yang relevan. Dengan demikian untuk memperoleh sumber belajar yang relevan, guru diharapkan untuk mengembangkan bahan ajar sebagai salah satu sumber belajar.

Berdasarkan observasi penulis di SMA Negeri 8 Kota Jambi diketahui bahwa pada kegiatan belajar mengajar sumber belajar yang digunakan guru adalah buku cetak oleh Noormandiri tahun 2016 yang di terbitkan dari penerbit Erlangga. Selain buku cetak tersebut sumber belajar lainnya adalah LKS.LKS yang digunakan merupakan LKS oleh Purwanto yang dibeli melalui penerbit yang datang kesekolah.

Namun dalam proses pembelajaran guru hanya terpaku pada buku cetak. LKS tersebut jarang digunakan, karena LKS tersebut hanya bersifat simbolik dan tidak mengaitkan antara materi barisan dan deret dengan kehidupan sehari-hari siswa. Hal tersebut menyebabkan siswa kesulitan untuk mengaplikasikan konsep yang mereka pelajari ke dalam permasalahan kehidupan sehari-hari. Selain itu di dalam kurikulum 2013 yang diterapkan saat ini terutama di SMA Negeri 08 Kota Jambi bahwa guru dan siswa dituntut untuk melakukan belajar dan pembelajaran dengan kontekstual yaitu mengaitkan dan mengaplikasikan konsep materi yang mereka pelajari ke dalam permasalahan kehidupan seharihari.

Oleh karena itu perlu dikembangkan suatu perangkat pembelajaran yang dapat membantu siswa dalam mengaitkan materi yang dipelajari dengan permasalahan yang ada dalam kehidupan sehari-hari. Kini peran guru dalam proses pembelajaran tidak lagi sebagai pemberi informasi, tetapi sebagai fasilitator bagi siswa dalam kegiatan belajar. Dalam pembelajaran matematika hendaknya guru memberikan kesempatan yang luas kepada siswa untuk terlibat aktif sehingga konsep materi yang dipelajari benar-benar tertanam dan mereka kuasai dengan baik. Pembelajaran matematika juga akan lebih bermakna jika siswa mampu mengaitkan apa yang mereka pelajari dengan kejadian yang terjadi pada kehidupan sehari-hari. Hal tersebut yang melatarbelakangi penulis untuk mengembangkan perangkat pembelajaran berupa Lembar Kerja Siswa (LKS) yang dapat memfasilitasi peserta didik dalam mengkonstruksi pengetahuan siswa.

Dengan demikian, seharusnya LKS yang tepat digunakan untuk meningkatkan hasil belajar siswa yaitu sebuah LKS yang di desain dan disajikan sesuai dengan tuntutan kurikulum 2013 yang diterapkan di sekolah terhadap mata pelajaran khususnya matematika dengan salah satu materi di dalamnya adalah materi barisan dan deret yang banyak ditemukan di dalam kehidupan sehari- 


\section{$\pi$ (Phi)}

hari siswa. Oleh karena itu penulis memilih materi barisan dan deret untuk dituangkan ke dalam LKS yang akan dikembangkan dengan basis Contextual Teaching and Learning (CTL).

Shoimin (2014) menjelaskan bahwa Contextual Teaching and Learning (CTL) merupakan suatu proses pembelajaran yang holistik dan bertujuan memotivasi siswa untuk memahami makna materi pelajaran yang dipelajarinya dengan mengaitkan materi tersebut dengan konteks kehidupan sehari-hari sehingga siswa memiliki pengetahuan/keterampilan yang secara fleksibel dapat diterapkan (ditransfer) dari satu permasalahan ke permasalahan lainnya. Jadi dengan begitu siswa dapat melakukan pembelajaran dimanapun dan kapan pun.

Pembelajaran dengan pendekatan CTL akan membantu siswa dalam pembelajaran khususnya matematika, sebagaimana dikemukakan oleh Suherman (2003) pendekatan kontektual dalam pembelajaran matematika berusaha untuk mengubah kondisi di atas, yaitu dengan membuat skenario pembelajaran yang dimulai dari konteks kehidupan nyata siswa (daily life). Selanjutnya guru memfasilitasi siswa untuk mengangkat objek dalam kehidupan nyata itu ke dalam konsep matematika, dengan melalui tanya jawab,diskusi, inkuiri, sehingga siswa dapat mengkontruksi konsep tersebut dalam pikirannya. Dengan demikian siswa belajar melalui 'doing math, hands on -activity'. Selain itu Suherman (2003) juga menyatakanpenerapan pendekatan kontekstual sejalan dengan tumbuh kembangnya matematika itu sendiri dan ilmu pengetahuan secara umum. Matematika tumbuh dan berkembang bukan melalui pemberitahuan, akan tetapi melalui inkuiri, kontruksivisme, tanya-jawab, dan semacamnya yang dimulai dari pengamatan pada kehidupan sehari-hari yang dialami secara nyata.

Berdasarkan masalah-masalah yang timbul di atas, tentu saja membutuhkan perhatian serius khususnya seorang pendidik agar mencari inovasi-inovasi pembelajaran matematika yang menjadikan pembelajaran lebih mudah dan bermakna. Maka perlu adanya pengembangan perangkat pembelajaran berupa LKS dengan pendekatan CTL pada materi barisan dan deret untuk mendukung kegiatan pembelajaran. Karena itu penulis tertarik untuk mengembangkan bahan ajar berupa Lembar Kerja Siswa (LKS) Berbasis Contextual Teachingand Learning (CTL) pada Materi Barisan dan Deret untuk Siswa SMA Kelas XI di SMA Negeri 8 Kota Jambi. LKS berbasis CTL pada materi barisan dan deret adalah LKS yang sesuai dengan karakteristik dan tujuan dari penerapan kurikulum 2013 yang menuntut guru dan siswa untuk melakukan pembelajaran secara kontekstual yaitu mengaitkan materi dengan kehidupan sehari-hari.

\section{METODE PENELITIAN}

Penelitian ini merupakan penelitian pengembangan (Research and Development) yang bertujuan untuk mengembangkan perangkat pembelajaran berupa LKS pada materi barisan dan deret. Model pengembangan penelitian ini merupakan penelitian pengembangan yang bertujuan untuk mengembangkan perangkat pembelajaran matematika berupa Lembar Kerja Siswa (LKS) pada materi barisan dan deret untuk SMA kelas XI dengan pendekatan Contextual 


\section{$\pi$ (Phi)}

Teaching and Learning (CTL) sesuai dengan kurikulum 2013.

Metode yang digunakan dalam penelitian ini adalah metode pengembangan ADDIE. Metode pengembangan ADDIE terdiri dari tahap analysis, design, development, implementation, dan evaluation, berikut tahapan-tahapannya:

1. Tahap Analisis (Analyze)

Langkah-langkah yang dilakukan pada tahap analisis adalah sebagai berikut:

a. Analisis Kurikulum

Pada tahapan analisis kurikulum berguna untuk mengetahui kurikulum yang digunakan di sekolah, mengetahui silabus dan kompetensi-kompetensi yang akan dicapai serta mengetahui materi-materi apa saja yang ada pada pelajaran matematika yang dapat dijadikan sebagai bahan materi untuk pembuatan Lembar Kerja Siswa (LKS) pelajaran matematika berupa Lembar Kerja Siswa (LKS) berbasis Contextual Teaching and Learning (CTL).

b. Analisis Karakteristik Siswa

Dalam pengembangan Lembar Kerja Siswa (LKS) karakteristik siswa perlu untuk diketahui untuk menyusun LKS yang sesuai dengan kpasitas belajar siswa, pengetahuan, keterampilan, sikap yang telah dimiliki siswa serta aspek lain yang terkait. Hal ini dapat dilakukan dengan bertanya kepada guru yang telah berpengalaman mengajar siswa.

c. Analisis Materi

Tahap ini dilakukan dengan cara mengidentifikasi materi utama sesuai dengan yang perlu diajarkan, materi yang dipilih sesuai dengan materi kurikulum yang berlaku dan menyusunnya secara sistematis. Sehingga materi pada LKS sesuai dengan kempetensi yang harus dikuasai siswa.

2. Tahap Perancangan (Design)

a. Persiapan Pembuatan Produk

Dalam persiapan pembuatan produk peneliti mencari dan mengumpulkan beberapa referensi buku matematika kelas XI dari berbagai sumber yang dianggap relevan untuk digunakan dalam mengembangkan Lembar Kerja Siswa (LKS).

b. Penyusunan Kerangka Dasar Lembar Kerja Siswa (LKS)

Yang dilakukan dalam penyusunan kerangka dasar Lembar Kerja Siswa (LKS) adalah membuat kerangka tentang apa saja yang disajikan dalam Lembar Kerja Siswa (LKS) yaitu berupa rancangan sampul, rancangan isi sesuai dengan struktur Lembar Kerja Siswa (LKS).

c. Penyusunan Instrumen Penilaian Instrumen penilaian produk dilakukan dengan angket penilaian untuk para ahli terhadap Lembar Kerja Siswa (LKS) yaitu ahli materi, ahli desain dan ahli media serta angket respon siswa untuk uji coba perorangan (one to one leaner), uji coba kelompok kecil (small group try-out) dan uji coba lapangan (field try-out).

3. Tahap

Pengembangan (Development)

Pada tahap ini peneliti membuat Lembar Kerja Siswa (LKS) berbasis Contextual Teaching and Learning (CTL) pada materi 


\section{$\pi$ (Phi)}

barisan dan deret, melakukan validasi Lembar Kerja Siswa (LKS) berbasis Contextual Teaching and Learning (CTL) pada materi barisan dan deret oleh 3 orang ahli, yaitu satu orang ahli materi, satu orang ahli media dan satu orang ahli desain, setelah itu melakukan uji coba perorangan dan uji coba kelompok kecil.

4. Tahap

Pelaksanaan

\section{(Implementation)}

Pada tahap ini peneliti melakukan uji coba produk pada kelas sesungguhnya yaitu di kelas XI SMA Negeri 8 Kota Jambi. Uji coba produk tersebut bertujuan untuk mengetahui kualitas produk dari aspek kepraktisan yang diperoleh dari tanggapan siswa dan efektifitas yang diperoleh dari hasil belajar siswa dengan menggunakan Lembar Kerja Siswa (LKS) berbasis Contextual Teaching and Learning (CTL) pada materi barisan dan deret yang dikembangkan.

5. Tahap Penilaian (Evaluate)

Pada pengembangan ADDIE ini evaluasi akan dilakukan pada setiap tahap mulai dari analisis, desain, pengembangan dan implementasi. Mulai dari rancangan sampul, rancangan isi, pembuatan produk, validitas desain, melakukan revisi sehingga pada tahap evaluasi akhir akan dihasilkan produk yang telah divalidasi oleh tim ahli sehingga LKS layak digunakan pada proses pembelajaran. Evaluasi yang dilakukan meliputi evaluasi formatif untuk mengumpulkan data dan evaluasi sumatif untuk mengetahui pengaruh LKS berbasis CTL pada hasil belajar siswa dan kualitas pembelajaran.

\section{HASIL DAN PEMBAHASAN}

Hasil pengembangan Lembar Kerja Siswa (LKS) berbasis Contextual Teaching and Learning (CTL) pada materi barisan dan deret siswa kelas XI di SMA Negeri 8 Kota Jambi. Pengembangan LKS yang mengikuti tahapan model ADDIE yaitu tahapan Analysis (Analisis), Design (Perancangan), Development (Pengembangan), Implementation (Implementasi) dan Evaluate (Evaluasi) , dilaksanakan dengan prosedur pengembangan sebagai berikut :

Lembar Kerja Siswa (LKS) pada materi Barisan dan Deret yang telah dikembangkan berdasarkan hasil penilaian para ahli yaitu ahli materi, ahli desain dan ahli media, uji coba perorangan, uji coba kelompok kecil dan uji coba lapangan. Adapun hasil analisis penilaian para ahli adalah sebagai berikut :

\section{Ahli Materi}

Bedasarkan hasil rekapitulasi hasil validasi LKS oleh ahli materi diperoleh skor rata-rata 4,3 sehingga termasuk kedalam kategori sangat baik. Dan apabila dihitung degan persentase maka LKS memperoleh nilai $86 \%$ sehingga termasuk kedalam kategori sangat baik dan sangat layak digunakan sebagai perangkat pembelajaran. Maka dari hasil penilaian ini maka LKS dinyatakan valid.Adapun rekapitulasi hasil penilaian LKS oleh ahli materi dapat dilihat pada Lampiran 21 halaman 173.

Selain analisis nilai secara keseluruhan, penilaian LKS dapat diketahui jika dilihat dari masingmasing aspek.Adapun aspek-aspek angket penilaian ahli materi meliputi aspek kecermatan isi, aspek ketetapan cakupan isi, aspek ketercernaan, aspek 
penggunaan bahasa dan aspek kelengkapan komponen.
Penilaian oleh ahli materi untuk setiap aspek dapat dilihat pada diagram berikut.

\section{Persentase Hasil Validasi Ahli Materi Dilihat Pada Setiap Aspek}

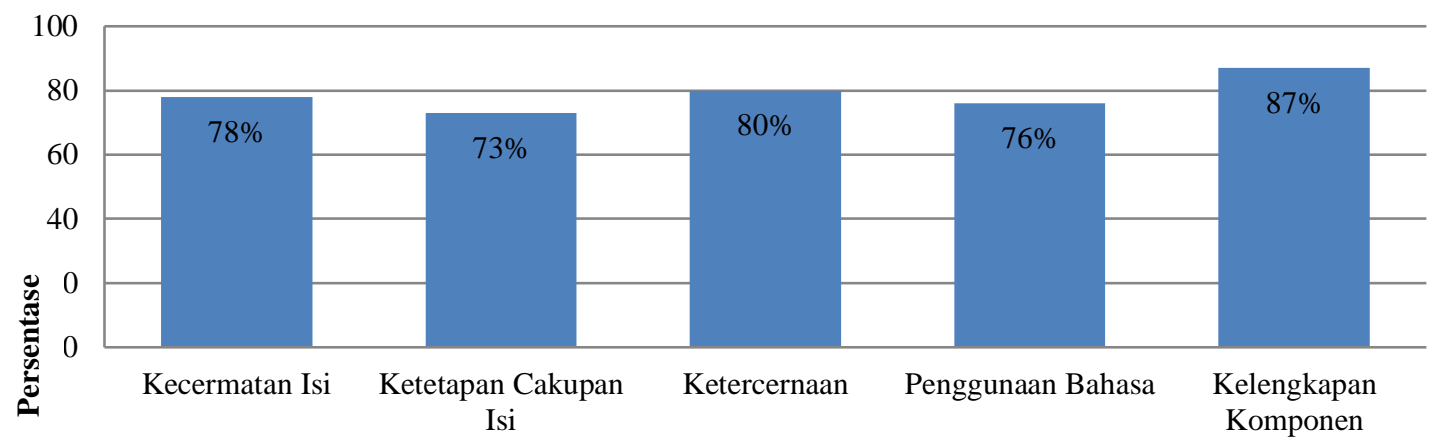

Gambar 1. Diagram Persentase Hasil Validasi Ahli Materi Dilihat Pada Setiap Aspek

Berdasarkan diagram hasil penilaian oleh ahli materi pada aspek kecermatan isi diperoleh persentase sebesar $78 \%$, pada aspek ketetapan isi cakupan isi deperoleh persentase sebesar $73 \%$, pada aspek ketercernaan deperoleh persentase sebesar 80\%, aspek penggunaan bahasa deperoleh persentase sebesar $76 \%$, dan aspek kelengkapan komponen deperoleh persentase sebesar $87 \%$.

Adapun revisi-revisi yang dilakukan berdasarkan masukan dari ahli materi adalah (1) membuat fasefase dari CTL di dalam LKS lebih bermakna bagi siswa dengan menjadikannya sebuah kalimat. Seperti pada fase-fase CTL yang pertama fase "constructivisme" menjadi "Let's construct your kmowlege", fase "inquiry" menjadikan "let's do an inquiry", fase "questioning" menjadi "let's answer the quetione", fase "modeling" menjadi "attention the example" dan pada fase "reflection" menjadi "make your reflection". (2) menghilangkan bagian keterangan yang tidak diperlukan. Sedangkan revisi yang dilakukan berdasarkan masukan dari ahli materi 2 adalah mengembangkan contoh soal dan membuat kolom isian untuk diisi oleh siswa.

\section{Ahli Desain}

Dari rekapitulasi hasil validasi LKS oleh ahli desain diperoleh skor rata-rata 3,71 sehingga LKS termasuk dalam kategori baik. Dan setelah dihitung dengan persentase, LKS mendapatkan nilai $74 \%$ sehingga termasuk ke dalam kategori sangat layak untuk digunakan sebgai salah satu perangkat pembelajaran.Dari hasil penilaian ini maka LKS dinyatakan valid.Rekapitulasi hasil penilaian ahli desain ini dapat dilihat pada lampiran 22 halaman 175.

Selain analisis nilai secara keseluruhan, penilaian LKS dapat diketahui jika dilihat dari masingmasing aspek. Adapun aspek-aspek angket penilaian ahli desain yaitu aspek kesesuaian LKS dengan 7 komponen CTL yang meliputi Konstruktivisme, Inquiry (menemukan sendiri), Questioning (bertanya), Learning community (masyarakat belajar), Modeling(pemodelan), Reflection (refleksi) dan Authentic Assessment (penilaian yang sebenarnya). 
Penilaian oleh ahli desain untuk

berikut setiap aspek dapat dilihat pada diagram

\section{Persentase Hasil Validasi Ahli Desain Dilihat Pada Setiap Aspek}

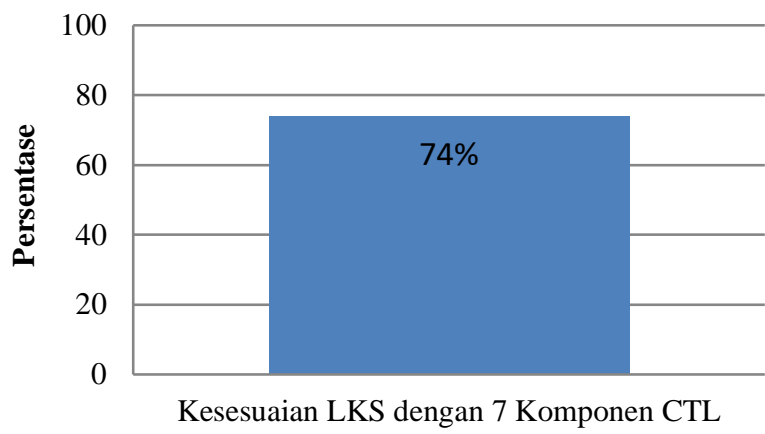

Gambar 2. Diagram Persentase Hasil Validasi Ahli Desain Dilihat Pada Setiap Aspek

Berdasarkan diagram hasil penilaian oleh ahli desain dilihat pada aspek kesesuaian LKS dengan 7 komponen CTL diperoleh persentase sebesar $74 \%$.

Adapun revisi-revisi yang dilakukan berdasarkan masukan ahli desain adalah (1) menghilangkan alternatif jawaban pada kegiatan satu. (2) mengganti angka-angka pecahan pada contoh soal menjadi angka-angka sederhana. (3) menambahkan kolom jawaban siswa pada kegiatan 1. (4) membuat uraian penemuan rumus dari barisan dan deret. (5) mengosongkan kolom kesimpulan.

\section{Ahli Media}

Berdasarkan hasil rekapitulasi hasil validasi LKS oleh ahli media diperoleh skor rata-rata 4,39 sehingga termasuk dalam kategori sangat baik.
Apabila dihitung dengan persentase, LKS mendapatkan nilai $87 \%$ sehingga termasuk dalam kategori sangat layak digunakan sebagai perangkat pembelajaran.Berdasarkan hasil penilaian tersebut maka kualitas LKS dinyatakan valid.Rekapitulasi hasil evaluasi LKS oleh ahli media dapat dilihat pada lampiran 23 halaman 176.

Selain analisis nilai secara keseluruhan, penilaian LKS dapat diketahui jika dilihat dari masingmasing aspek.Adapun aspek-aspek angket penilaian ahli media yaitu aspek desain tampilan, aspek layout dan tata letak, aspek penggunaan font, aspek mutu gambar, aspek perwajahan dan aspek kelengkapan komponen.

Penilaian ahli media untuk setiap aspek dapat dilihat pada diagram berikut. 


\section{Persentase Hasil Validasi Ahli Media Dilihat Pada Setiap Aspek}

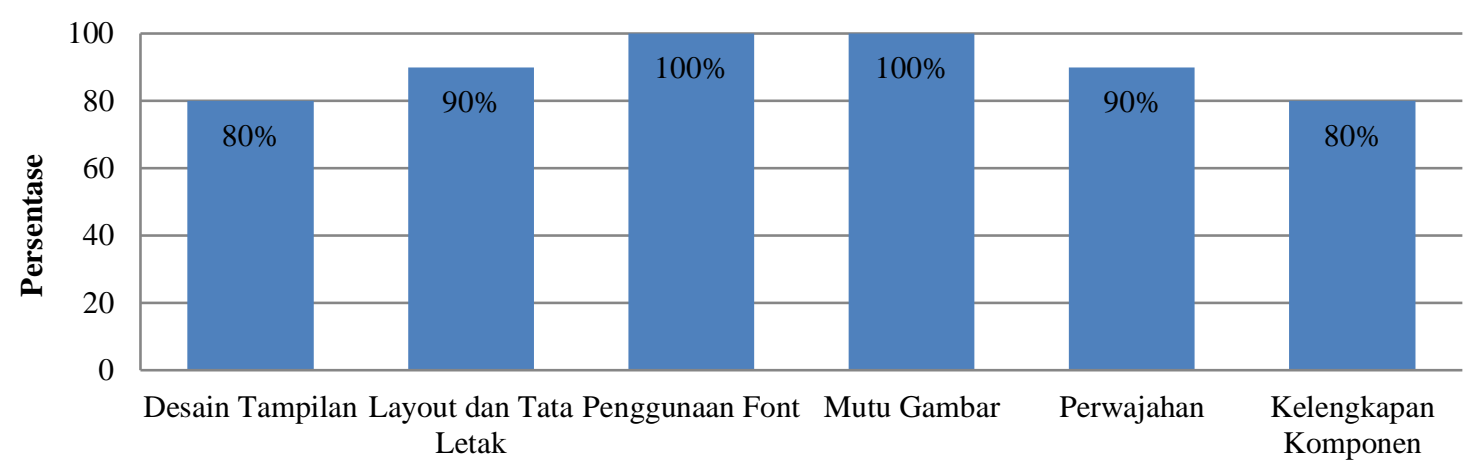

Gambar 3. Diagram Persentase Hasil Validasi Ahli Media Dilihat Pada Setiap Aspek

Berdasarkan diagram dari hasil penilaian oleh ahli media dilihat pada aspek desain tampilan diperoleh persentase sebesar $80 \%$, pada aspek layout dan tata letak diperoleh persentase sebesar 90\%, pada aspek penggunaan font diperoleh persentase sebesar $100 \%$, aspek mutu gambar diperoleh persentase sebesar 100\%, aspek perwajahan diperoleh persentase sebesar 90\%, dan aspek kelengkapan komponen diperoleh persentase sebesar $80 \%$.

Adapun revisi-revisi yang dilakukan sesuai dengan saran dari ahli media yaitu pada revisi 1, revisi dilakukan dengan mengganti warna latar cover menjadi warna biru dan memperjelas gambar cover, mendesain font dengan lebih menarik dan menggunakan warna yang sedikit cerah. Pada revisi 2, revisi dilakukan dengan mengganti gambar pada cover LKS dengan gambar yang lebih menarik dan menambakan karakter matematika yang sesuai dengan materi yaitu angka barisan dan deret.

\section{Uji Coba Perorangan}

Uji coba yang digunakan membuktikan kepraktisan itu disebut dengan evaluasi formatif.Tujuan dari evaluasi formatif untuk menemukan kelemahan-kelemahan dalam sebuah desain pembelajaran.Dan dengan adanya kekurangan itu nantinya bisa direvisi dan akhirnya bisa mendapatkan suatu bentuk pembelajaran yang efektif dan efesien.

Berdasarkan hasil rekapitulasi hasil validasi LKS pada uji coba perorangan oleh 3 orang siswa kelas XI IPS diperoleh skor rata-rata 4,5 sehingga termasuk dalam kategori sangat baik. Apabila dihitung dengan persentase, LKS mendapatkan nilai $88 \%$ sehingga termasuk dalam kategori sangat layak digunakan sebagai perangkat pembelajaran.Berdasarkan hasil penilaian tersebut maka kualitas LKS dinyatakan valid.Rekapitulasi hasil evaluasi LKS pada uji coba perorangan dapat dilihat pada lampiran 27 halaman 200.

Selain analisis nilai secara keseluruhan, penilaian LKS dapat diketahui jika dilihat dari masingmasing aspek. Adapun aspek-aspek angket penilaian siswa untuk uji coba perorangan yaitu aspek ketepatan struktur kalimat,aspek ketepatan tata bahasa, aspek ketepatan ejaan dan aspek kejelasan petunjuk penggunaan LKS. 
Penilaian siswa pada uji coba perorangan untuk setiap aspek dapat

dilihat pada diagram berikut.

\section{Persentase Hasil Uji Coba Perorangan Dilihat Pada Setiap Aspek}

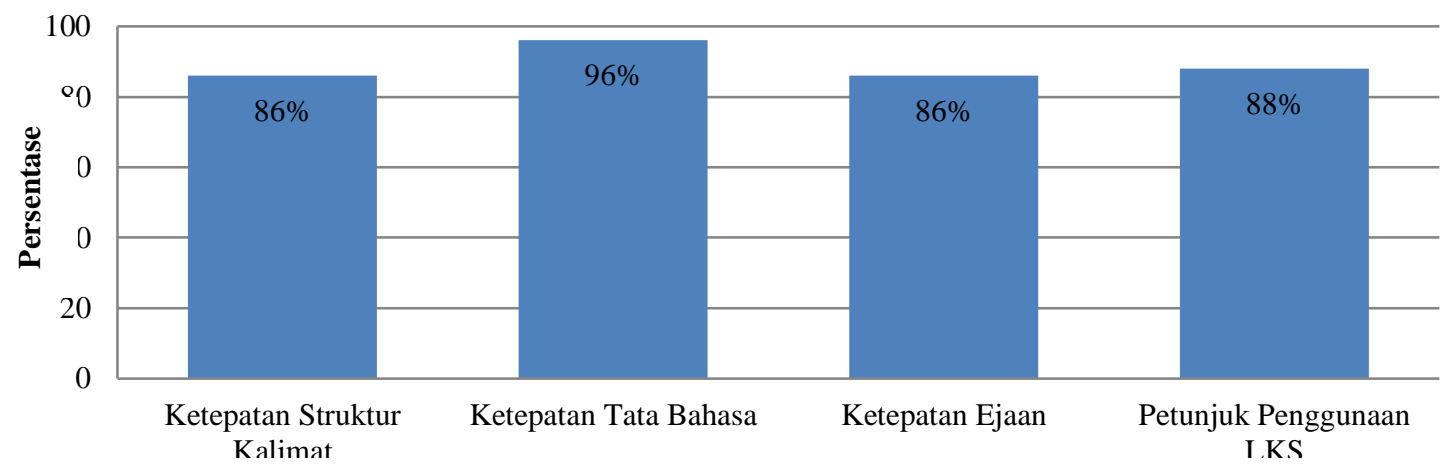

Gambar 4. Diagram Persentase Hasil Uji Coba PeroranganDilihat Pada Setiap Aspek

Berdasarkan diagram hasil penilaian pada uji coba perorangan oleh siswa dilihat pada aspek ketepatan struktur kalimat diperoleh pesentase sebesar 86\%, aspek ketepatan tata bahasa diperoleh pesentase sebesar 96\%,, aspek ketepatan ejaan diperoleh pesentase sebesar 86\%, dan aspek kejelasan petunjuk penggunaan LKS diperoleh pesentase sebesar $88 \%$. Adapun revisi-revisi yang dilakukan terhadap LKS berdasarkan hasil uji coba perorangan pada tiga orang siswa yang mereka bawa pulang kerumah masing-masing adalah tidak ada.

\section{Uji Coba Kelompok Kecil}

Berdasarkan hasil rekapitulasi hasil validasi LKS pada uji coba kelompok kecil oleh 6 orang siswa kelas XI IPS 2 diperoleh skor rata-rata 4,5 sehingga termasuk dalam kategori sangat baik. Apabila dihitung dengan persentase, LKS mendapatkan nilai 90\% sehingga termasuk dalam kategori sangat layak digunakan sebagai perangkat pembelajaran.Berdasarkan hasil penilaian tersebut maka kualitas LKS dinyatakan valid.Rekapitulasi hasil evaluasi LKS pada uji coba kelompok kecil dapat dilihat pada lampiran 28 halaman 201.

Selain analisis nilai secara keseluruhan, penilaian LKS dapat diketahui jika dilihat dari masingmasing aspek.Adapun aspek-aspek angket penilaian siswa pada uji coba kelompok kecil yaitu aspek kejelasan tujuan pembelajaran, aspek keakuratan gambar diagram dan ilustrasi, aspek kebakuan istilah, dan aspek pemahaman terhadap pesan atau informasi.

Penilaian siswa pada uji coba kelompok kecil untuk setiap aspek dapat dilihat pada diagram berikut. 


\section{Persentase Hasil Uji Coba Kelompok Kecil Dilihat Pada Setiap Aspek}

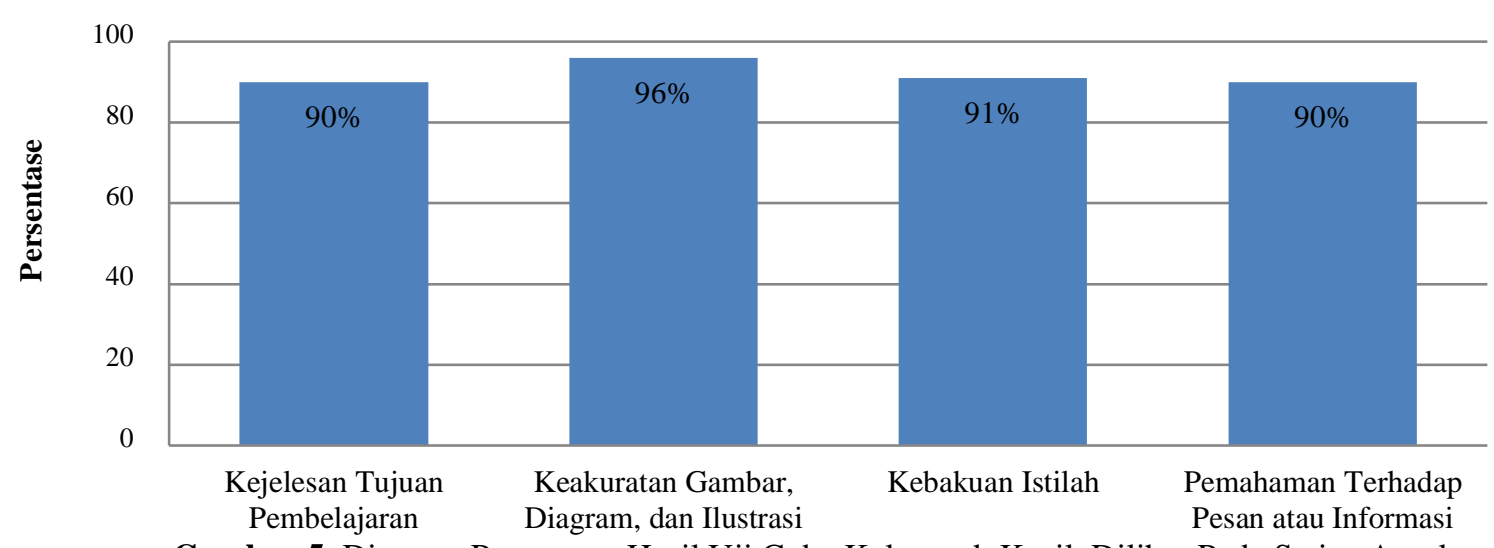

Gambar 5. Diagram Persentase Hasil Uji Coba Kelompok Kecil Dilihat Pada Setiap Aspek

Berdasarkan diagram hasil penilaian pada uji coba perorangan oleh siswa dilihat pada aspek kejelasan tujuan pembelajaran diperoleh pesentase sebesar 90\%, aspek keakuratan gambar diagram dan ilustrasi diperoleh pesentase sebesar $96 \%$, aspek kebakuan istilah diperoleh pesentase sebesar 91\%, dan aspek pemahaman terhadap pesan atau informasi diperoleh pesentase sebesar $90 \%$.

Adapun revisi-revisi yang dilakukan terhadap LKS berdasarkan hasil uji coba kelompok kecil adalah memperbaiki rumus yang digunakan pada kegiatan 3 .

\section{Uji Coba Lapangan}

Berdasarkan hasil rekapitulasi hasil validasi LKS pada uji coba lapangan yang melibatkan satu kelas siswa kelas XI IPS 1 diperoleh skor rata-rata 4,37 sehingga termasuk dalam kategori sangat baik. Apabila dihitung dengan persentase, LKS mendapatkan nilai $87 \%$ sehingga termasuk dalam kategori sangat layak digunakan sebagai perangkat pembelajaran.Berdasarkan hasil penilaian tersebut maka kualitas
LKS dinyatakan valid.Pada uji coba lapangan ini tidak ada bagian LKS yang direvisi.Rekapitulasi hasil evaluasi LKS pada uji coba lapangan dapat dilihat pada lampiran 29 halaman 202.

Selain analisis nilai secara keseluruhan, penilaian LKS dapat diketahui jika dilihat dari masingmasing aspek.Adapun aspek-aspek angket penilaian siswa pada uji coba lapangan yaitu aspek kemudahan, aspek keterbantuan dan aspek kebermanfaatan.Dimana untuk aspek kemudahan terdiri atas indikator penilaian kemudahaan penggunaan LKS, dan kemudahan mengikuti kegiatan pembelajaran.Aspek keterbantuan terdiri atas indikator penilaian keterbantuan siswa dalam memahami materi menggunakan LKS, dan keterbantuan siswa dalam mengikuti kegiatan pembelajaran. Aspek kebermanfaatan terdiri atas indikator penilaian Kebermanfaatan penggunaan LKS dalam memahami materi, dan kebermanfaatan penyajian pertanyaan-pertanyaan dalam proses pembelajaran.

Berikut diagram penilaian siswa pada uji coba lapangan untuk setiap aspek. 


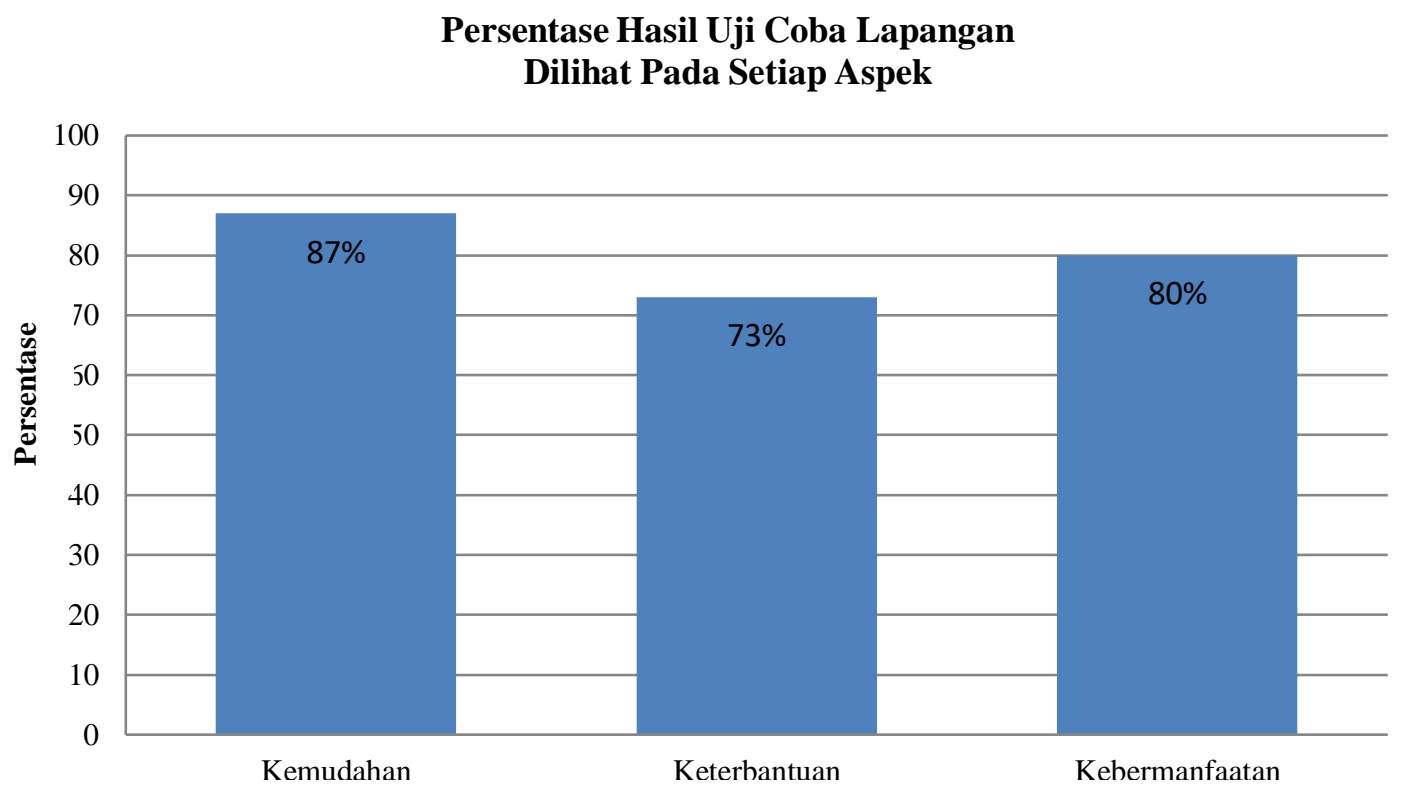

Gambar 6. Diagram Persentase Hasil Uji Coba Lapangan Dilihat Pada Setiap Aspek

Berdasarkan diagram hasil penilaian pada uji coba lapangan oleh siswa dilihat pada aspek kemudahan diperoleh pesentase sebesar $87 \%$, aspek keterbantuan diperoleh pesentase sebesar $73 \%$, dan aspek kebermanfaatan $80 \%$. Adapun revisirevisi yang dilakukan terhadap LKS berdasarkan hasil uji coba lapangan yang melibatkan 6 orang siswa yang mereka dipersilahkan untuk membawa LKS untuk dikerjakan atau diisi di rumah masing-masing adalah tidak ada.

\section{SIMPULAN DAN SARAN}

Berdasarkan uraian pada hasil penelitian dan pembahasan penulis dapat menyimpulkan bahwa pengembangan Lembar Kerja Siswa (LKS) berbasis Contextual Teaching and Learning (CTL) pada materi barisan dan deret siswa kelas XI SMA Negeri 8 Kota Jambi dilakukan melalui lima tahap pengembangan menurut Model Pengembangan ADDIE. Tahap pengembangan menggunakan model ADDIE diawali dengan tahap Analysis (Analisis), Design (Perancangan),
Development (Pengembangan), Implementation (Implementasi) dan Evaluate (Evaluasi).

Adapun kualitas Lembar Kerja Siswa (LKS) berbasis Contextual Teaching and Learning (CTL) pada materi barisan dan deret dilihat dari aspek kevalidan, aspek kepraktisan dan aspek keefektifan adalah sebagai berikut:

1. Dilihat dari aspek kevalidan

Berdasarkan penilaian oleh ahli materi, LKS yang dikembangkan memperoleh skor rata-rata 4,3 sehingga termasuk kategori sangat baik. Jika dihitung ke dalam persentase, LKS mendapatkan nilai $80 \%$ sehingga termasuk dalam kategori sangat valid untuk digunakan sebagai perangkat pembelajaran.

Berdasarkan penilain ahli desain, LKS yang dikembangkan memperoleh skor rata rata 3,71 sehingga termasuk kategori baik. Jika dihitung ke dalam persentase, LKS mendapatkan nilai 74\%.Berdasarkan kriteria kevalidan 
maka LKS termasuk ke dalam kategori valid untuk digunakan sebagai perangkat pembelajaran.

Berdasarkan penilaian ahli media, LKS yang dikembangkan memperoleh skor rata-rata 4,39 sehingga termasuk kategori sangat baik. Jika dihitung ke dalam persentase, LKS mendapatkan nilai 87\%.Maka LKS berbasis CTL termasuk ke dalam kategori sangat valid untuk digunakan sebagai perangkat pembelajaran.

2. Dilihat dari aspek kepraktisan Dilihat dari aspek kepraktisan, LKS yang dikembangkan yaitu LKS berbasis CTL memperoleh kriteria praktis. Hal tersebut dilihat dari angket respond siswa memperoleh skor rata-rata 4,37 maka termasuk ke dalam kategori sangat baik dengan persentase $80 \%$ dengan kategori sangat praktis.

3. Dilihat dari aspek keefektifan Dilihat dari aspek keefektifan, LKS yang dikembangkan memperoleh kriteria efektif.Hal tersebut terlihat dari perhitungan persentase hasil tes. Diperoleh persentase siswa yang tuntas adalah $92,5 \%$ sehingga LKS berbasis CTL yang dikembangkan memiliki tingkat keefektifan yang sangat baik, sangat efektif digunakan sebagai perangkat pembelajaran.

\section{DAFTAR PUSTAKA}

Akbar, Sau'dun. 2013. Instrumen Perangkat Pembelajaran. PT Remaja Rosdakarya. Bandung.

Amri, Sofan dan Khoiru Ahmadi. 2010.

\begin{tabular}{|c|c|c|}
\hline Kontruksi & \multicolumn{2}{|c|}{ Pengembangan } \\
\hline Pembelajaran: & & \\
\hline Pengaruhnya & & Terhadap \\
\hline Mekanisme & dan & Praktik \\
\hline Kurikulum.Pres & & Pustaka \\
\hline
\end{tabular}

Aqib, Zainal. 2013. Model-Model dan Strategi Pembelajaran Kontekstual Inovatif. CV Yrama Widya. Bandung.

Daryanto. 2009. Panduan Pembelajaran: Kreatif dan Inovatif. AV Publisher. Jakarta.

Depdiknas.2008. Panduan Pengembangan Bahan Ajar.Depdiknas. Jakarta.

Gafur, Abdul. 2012. Desain Pembelajaran. Penerbit Ombak Dua. Yogyakarta.

Hamalik, Oemar. 2011. Proses Belajar Mengajar. Bumi Aksara. Jakarta.

Hanafiah, Nanang dan Cucu Suhana. 2009. Konsep Strategi Pembelajaran. Refika Aditama. Bandung.

Hasratuddin. 2014. Membangun Karakter Melalui Pembelajaran Matematika:Jurnal Pendidikan Matematika Paradikma. 6 (2).

Lestari, Karunia Eka dan Mokhamad Ridwan Yudanegara. 2015. Penelitian Pendidikan Matematika. PT Refika Aditama. Bandung.

Muchtith, Saekhan. 2007. Pembelajaran Kontekstual. Rasail Media Group.Kudus.

Prawiradilaga, Dewi Salma. 2007. Prinsip Desain Pembelajaran. Kencana Media Group. Jakarta.

Permendikbud No 69.2013. Kerangka Dasar dan Struktur Kurikulum SMA/MA.Permendikbud. Jakarta.

.No 103. 2014. Pembelajaran Pada Pendidikan Dasar Dan Pendidikan Menengah. Permendikbud. Jakarta.

Prastowo, Andi. 2011. Panduan Kreatif Membuat Bahan Ajar Inovatif.DIVA Press. Yogyakarta.

Rochmad. 2012. Desain Model Pengembangan Perangkat 
Pembelajaran Matematika:Jurnal Kreano.3 (1)

Sudjana. 2005. Metoda Statistika.

Tarsito. Bandung.

Sugiyono, Joko. 2006 Metode

Penelitian Kuantitatif Kualitatif dan $R \& D$.Alfabet. Bandung.

Trianto. 2009. Mendesain Model Pembelajaran Inovatif Progresif: Konsep Landasan dan Implementasinya pada Kurikulum Tingkat Satuan Pendidikan (KTSP). Kencana Perdana Media Grup. Jakarta.

-2007. Model Pembelajaran Terpadu dalam Teori dan Paraktek. Jakarta: Prestasi Pustaka Publisher.

Tegeh, I Made. Dkk. 2014.Model Penelitian Pengembangan. Yogyakarta: Graha Ilmu. 